\title{
GENETIC PARAMETERS OF Eucalyptus spp. CLONES IN NORTHEASTERN BRAZIL
}

\author{
Rodrigo de Andrade Furlan ${ }^{1 *}$, Cristiano Bueno de Moraes $^{2}$, Evandro Vagner Tambarussi ${ }^{1,3}$ \\ 1*Universidade Estadual Paulista, Programa de Pós-Graduação em Ciência Florestal, Botucatu, São Paulo, Brasil - furlanra@ gmail.com \\ ${ }^{2}$ Universidade Federal do Tocantins, Departamento de Engenharia Florestal, Gurupi, Tocantins, Brasil - cbmoraes@mail.uft.edu.br \\ ${ }^{3}$ Universidade Estadual do Centro-Oeste, Departamento de Engenharia Florestal,Irati, Paraná, Brasil - tambarussi@ gmail.com
}

Received for publication: 25/10/2018 - Accepted for publication: 07/12/2018

\begin{abstract}
Resumo
Parâmetros genéticos em clones de Eucalyptus spp. no nordeste do Brasil. O Brasil está entre os maiores produtores de carvão vegetal do mundo, sendo que os principais polos de consumo de carvão estão localizados nos estados de Minas Gerais, Mato Grosso do Sul, Espírito Santo, Maranhão e Pará. A cultura do eucalipto nos estados do Norte e Nordeste do Brasil é relativamente nova e tem como limitação a pouca seleção de materiais adaptados as altas temperaturas e o severo e prolongado período de déficit hídrico. O objetivo desta pesquisa foi estudar a variabilidade, os parâmetros genéticos e determinar a interação genótipos $\mathrm{x}$ ambientes para a tolerância à seca, em testes clonais de eucaliptos plantados em dois ambientes no município de Grajaú, estado do Maranhão. Os testes foram plantados em janeiro de 2011, em solos argiloso e arenoso, com 130 clones, no delineamento de blocos casualizados, com uma planta por parcela e 20 repetições. Os clones de eucalipto estudados apresentaram alta variabilidade genética para a tolerância à seca, com coeficientes de variação relativa $\left(\widehat{C V}_{r}\right)$ sempre superiores a 0,8 para DAP e volume, indicando maior controle genético e menor influência dos fatores ambientais no fenótipo, o que permite a seleção e obtenção de ganhos no melhoramento. As estimativas das herdabilidades foram altas para os caracteres de crescimento, com herdabilidades médias dos clones $\left(\hat{h}_{m}^{2}\right)$ superiores a 0,85 , assim como acurácias $\left(\hat{r}_{a a}\right)$, superiores a 0,9 para DAP e volume na seleção dos clones. Houve interação simples entre genótipos x ambientes para os clones, nas condições de variação de solo.
\end{abstract}

Palavras-chave: Espécies de eucalipto. Silvicultura clonal. Parâmetros genéticos. Melhoramento florestal. Tolerância à seca.

Abstract

Brazil is the largest charcoal producers in the world, with the main centers of charcoal consumption located in the states of Minas Gerais, Mato Grosso do Sul, Espírito Santo, Maranhão, and Pará. Planting of Eucalyptus in the northern and northeastern states of Brazil is relatively new and is limited the lack of genetic materials adapted to the region's high temperatures and severe, prolonged periods of drought. The objective of this study was to assess the genetic parameters and variability and determine the genotype $\mathrm{x}$ environment interaction for drought tolerance in Eucalyptus clonal tests established in two environments in the municipality of Grajaú, Maranhão State, Brazil. The tests were planted in January 2011 in clayey and sandy soils in a randomized complete block design with 130 clones, one plant per plot, and 20 replicates. The studied clones showed high genetic variability for drought tolerance, with coefficients of relative variance $\left(\widehat{C V}_{r}\right)$ consistently greater than 0.8 for DBH and volume. This indicates high levels of genetic control and less influence of environmental factors on the phenotype, which allows for selection and obtaining gains through breeding. Heritability estimates were high for growth traits, with average clone heritabilities $\left(\hat{h}_{m}^{2}\right)$ greater than 0.85 , as well as acuracies $\left(\hat{r}_{a a}\right)$ above 0.9 for DBH and volume in clone selection. There was a simple interaction between genotype $\mathrm{x}$ environment for the clones under the two different soil conditions.

Keywords: Eucalyptus spp. Clone silviculture. Genetic analysis. Forest breeding. Drought tolerance.

\section{INTRODUCTION}

Brazil is among the main producers of crude steel and pig iron, and charcoal is one of the most important fuel sources for the national steel industry. In 2016, the national steel industry consumed 4.5 million tons of charcoal (IBÁ, 2017). In the same year, the total area of trees planted in Brazil was 7.84 million hectares; of which, $34 \%$ belongs to cellulose and paper companies, $29 \%$ are independently owned or rented (small and medium-sized producers that invest in forest plantations for the commercialization of raw wood), and $14 \%$ produce charcoal for the steel industry(IBÁ, 2017).

In the country, there more than 120 industries that use charcoal to produce pig iron, iron alloys, and steel, with the main centers of charcoal consumption located in the states of Minas Gerais, Mato Grosso do Sul, Espírito Santo, Maranhão, and Pará (IBÁ, 2017). However, the cultivation of eucalypts in the north and northeastern states of Brazil, such as Alagoas, Maranhão, Pará, Piauí, and Tocantins, is relatively new and significantly limited by the lack of selected genetic materials that are adapted to the high temperatures and severe, prolonged periods of

FLORESTA, Curitiba, PR, v. 50, n. 2, p. 1267 - 1278, abr/jun 2020.

Furlan, R. A. et.al.

ISSN eletrônico 1982-4688 
drought. According to Stape et al.(2004),water availability is the most limiting factor in the fertilized planting of Eucalyptus.

The first commercial scale plantations in the region were established in the mid-1980s and were used to select genetic material for the southeast, with the genetic foundation being the species Eucalyptus grandis Hill ex Maiden and Eucalyptus urophylla S. T. Blake. With the increase in planted area and development of genetic improvement throughout Brazil, many commercial clones, mostly hybrids, have been introduced. However, selections specific to the north and northeast only began in the last twenty years. The lack of information about the development of forest plantations in the northeast demonstrates the need for further analysis of the species, proveniences of rapid growth, and possibilities of adaptation to the region, to support reforestation programs (PUPIN et al., 2015).

The capability of genetic material to perform well under a wide range of environmental conditions is an essential factor in improvement programs (MORAES et al., 2014; ENGEL et al., 2016; PUPIN et al., 2018). The term adaptability is used to designate the capacity of the genetic material to take advantage of environmental stimuli, and stability refers to the capacity of genotypes to be have predictably in the face of environmental stimuli (VENCOVSKY; BARRIGA, 1992; MORAIS et al., 2010). The environment can affect responses of genotypes in terms of adaptability and stability due to the genotype $\mathrm{x}$ environment interaction, which can cause a reduction in genetic gains when the selection is realized simultaneously in different environments (SANTOS et al., 2016; TEODORO et al., 2016). As such, understanding the environmental effect is critical in the selection of productive genetic material (OLIVEIRA et al., 2018).

Information about adaptation and the genetic potential of Eucalyptus in conditions of drought are necessary due to the territorial expansion of the cultivation of the genus, mainly in regions that are considered forestry frontiers (ANDRADE et al., 2018). In all regions near to the equator that have severe conditions of high temperatures and drought, including Brazil, there are limitations to the cultivation of Eucalyptus clones. Thus, knowledge about the variations and genetic parameters of the clones, such as the genotype $\mathrm{x}$ environment interaction effects, are important to ensure the success of clonal Eucalyptus forestry in such tropical regions.

The objective of the present study is to assess two Eucalyptus spp. clonal tests, at six years of age, established under different soil conditions (clay and sandy soil) in Grajaú, Maranhão State. Specifically, we sought to: (i) estimate the variability and genetic parameters for the traits diameter at breast height $(\mathrm{DBH}, \mathrm{cm})$, height $(\mathrm{H}$, $\mathrm{m})$, and volume $\left(\mathrm{V}, \mathrm{m}^{3}\right)$; and (ii) verify the interaction effects between clones and different environments (clay and sandy soils).

\section{MATERIAL AND METHODS}

Two identical clonal tests were established using 130 Eucalyptus spp. clones, including 118 clones obtained by screening individuals from commercial plantations, and a control sample of 12 publicly available, commercial clones that are used in the north and northeast regions. The clonal tests belong to the Genetic Improvement Program of the company Gusa Nordeste S. A., a member of the Ferroeste Group. The clonal tests were installed at the Fazenda Sibéria in the municipality of Grajaú, Maranhão, in blocks $102\left(5^{\circ} 41^{\prime} 1,37^{\prime \prime} \mathrm{S}\right.$ and $\left.45^{\circ} 42^{\prime} 0,75^{\prime \prime O}\right)$ and $155\left(5^{\circ} 45^{\prime} 25,57^{\prime \prime} \mathrm{S}\right.$ and 45 $\left.39^{\prime} 41,73^{\prime \prime O}\right)$, in January 2011.

Selection of the plus tress were conducted in commercial plantations established from seeds, and later identified phenotypically as E.urophylla, Eucalyptus grandis x E.urophylla hybrid, Eucalyptus pellita F. Muell, Eucalyptus camaldulensis Dehne and Eucalyptus tereticornis Smith. The source plantations are located in the municipality of Grajaú and Barra do Corda, Maranhão, where Gusa Nordeste's forest sites are distributed. It is important to note that natural hybrids occur within these seeded plantations, and some of the selected plus trees may be hybrids selected for vigor.

According to the Köppen classification, the region presents an Aw type tropical climate, with rainy summers and dry winters, and the driest month experiencing less than $60 \mathrm{~mm}$ of precipitation. The average temperature of the coldest month is greater than $18^{\circ} \mathrm{C}$ and the annual average temperature is around $26^{\circ} \mathrm{C}$. The average precipitation is approximately $1200 \mathrm{~mm}$, with most of the precipitation occurring during the first trimester of the year (ALVARES et al., 2013).

Data on average precipitation and temperature throughout the evaluation period of the clonal tests were obtained from a weather station belonging to the National Meteorology Institute (INMET, 2018), located in the municipality Barra do Corda, (Figure 1) approximately $50 \mathrm{~km}$ from the test sites. The data show a period in which the quantity of rain is below the historical average, and can be considered a period of elevated drought.

The predominant soils of the region are the Yellow Latosols, characterized by low fertility, high permeability, and high levels of iron and aluminum. Less commonly, there is also the occurrence of soils classified as Red Podzolic, Red-Yellow Podzolic and Luvisols (EMBRAPA, 2013). 

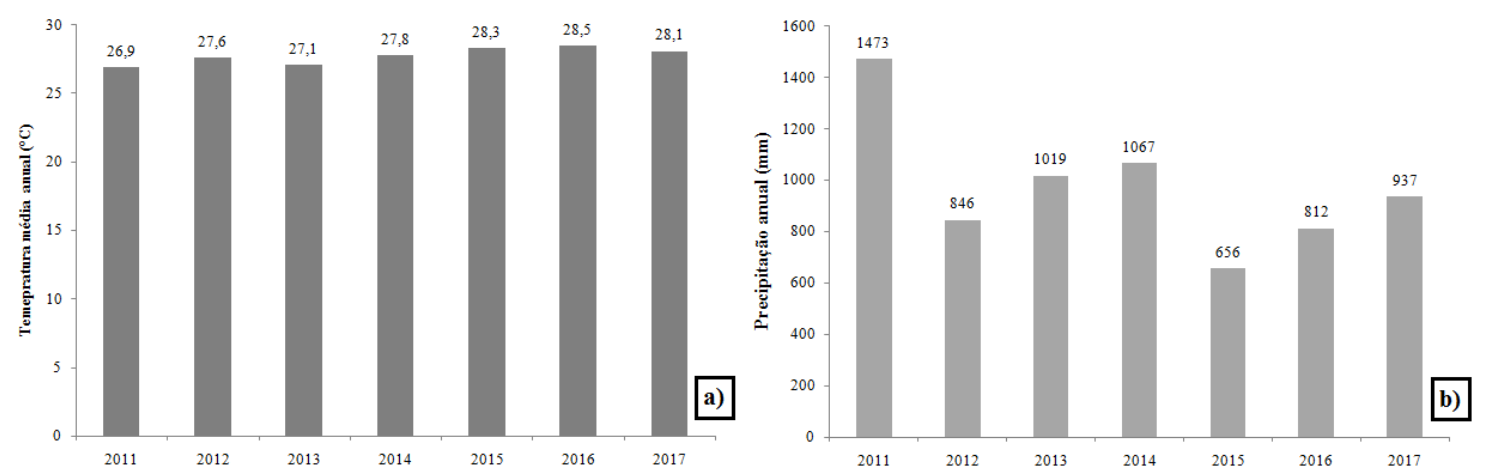

Figura 1: Temperatura média anual em ${ }^{\circ} \mathrm{C}$ (a) e precipitação anual em mm (b) entre os anos de 2011 e 2017 em Barra do Corda, estado do Maranhão (INMET, 2018).

Figure 1: Average annual temperature in ${ }^{\circ} \mathrm{C}$ (a) and annual precipitation in mm (b) between 2011 and 2017 in Barra do Corda, Maranhão State (INMET, 2018).

Before planting of the clonal tests, the land cover in these areas was native cerrado where native vegetation was suppressed. After an initial regeneration of the native vegetation, a new suppression was conducted prior to planting. Soil analysis was conducted at the two sites before planting and the composed soil samples were collected at a depth of 0-20 cm and 20-40 cm for chemical analysis (Table 1) and 0-20 cm for physical analysis (Table 2). The analyses were conducted in the Brazilian Agricultural Analysis Laboratory Ltda. (LABRAS).

Tabela 1. Resultados da análise química de solo dos Talhões 102 e 155, para as profundidades de 0-20 e 20-40 cm, dos testes clonais de Eucalyptus spp., localizados no município de Grajaú, estado do Maranhão.

Table 1. Results of soil chemical analysis for 0-20 and 20-40 cm depths, from planting blocks 102 and 155 of Eucalyptus spp. clonal tests located in Grajaú, Maranhão State.

\begin{tabular}{|c|c|c|c|c|c|}
\hline \multirow{2}{*}{$\begin{array}{l}\text { Chemical } \\
\text { composition }\end{array}$} & \multirow[t]{2}{*}{ Unit } & \multirow{2}{*}{$\begin{array}{c}\text { Block } 102 \\
0-20 \mathrm{~cm}\end{array}$} & & \multirow{2}{*}{$\begin{array}{l}\text { Block155 } \\
0-20 \mathrm{~cm}\end{array}$} & \multirow[b]{2}{*}{$20-40 \mathrm{~cm}$} \\
\hline & & & $20-40 \mathrm{~cm}$ & & \\
\hline $\mathrm{pH} \mathrm{H} \mathrm{H}_{2} \mathrm{O}$ & $1: 2.5$ & 4.7 & 4.7 & 4.9 & 5.3 \\
\hline $\mathrm{pH} \mathrm{CaCl} 2$ & $1: 2.5$ & 4.2 & 4.1 & 3.9 & 3.9 \\
\hline $\mathrm{P} \mathrm{meh}^{-1}$ & mg.dm ${ }^{-1}$ & 3.6 & 1.8 & 4.0 & 4.0 \\
\hline $\mathrm{K}^{+}$ & $\mathrm{cmol}_{\mathrm{c}} \cdot \mathrm{dm}^{-3}$ & 0.08 & 0.04 & 0.12 & 0.08 \\
\hline $\mathrm{Ca}^{2+}$ & $\mathrm{cmol}_{\mathrm{c}} \cdot \mathrm{dm}^{-3}$ & 0.60 & 0.50 & 0.31 & 0.37 \\
\hline $\mathrm{Mg}^{2+}$ & $\mathrm{cmol}_{\mathrm{c}} \cdot \mathrm{dm}^{-3}$ & 0.30 & 0.25 & 0.23 & 0.20 \\
\hline $\mathrm{Al}^{3+}$ & $\mathrm{cmol}_{\mathrm{c}} \cdot \mathrm{dm}^{-3}$ & 0.85 & 0.94 & 1.22 & 1.26 \\
\hline $\mathrm{H}+\mathrm{Al}$ & $\mathrm{cmol}_{\mathrm{c}} \cdot \mathrm{dm}^{-3}$ & 6.05 & 5.40 & 10.94 & 10.47 \\
\hline M.O. & g. $\mathrm{kg}^{-1}$ & 26 & 23 & 39 & 36 \\
\hline SB & $\mathrm{cmol}_{\mathrm{c}} \cdot \mathrm{dm}^{-3}$ & 0.98 & 0.79 & 0.65 & 0.65 \\
\hline $\mathrm{T}$ & $\mathrm{cmol}_{\mathrm{c}} \cdot \mathrm{dm}^{-3}$ & 7.03 & 6.19 & 11.62 & 11.11 \\
\hline V & $\%$ & 15 & 13 & 6 & 6 \\
\hline M & $\%$ & 48 & 57 & 64 & 65 \\
\hline
\end{tabular}

Tabela 2. Resultados da análise física de solo dos Talhões 102 e 155, para a profundidade de 0-20 cm, dos testes clonais de Eucalyptus spp., localizados no município de Grajaú, estado do Maranhão.

Table 2. Results of physical soil analysis from samples at a depth of 0-20 cm from planting blocks 102 and 155 of Eucalyptus spp. clonal tests located in Grajaú, Maranhão State.

\begin{tabular}{lccc}
\hline Characteristic & Unit & Block102 & Block 155 \\
\hline Total sand & $\mathrm{g} \cdot \mathrm{kg}^{-1}$ & 338 & 840 \\
Silt & $\mathrm{g} \cdot \mathrm{kg}^{-1}$ & 106 & 45 \\
Clay & $\mathrm{g} \cdot \mathrm{kg}^{-1}$ & 556 & 115 \\
Classification & & Clay & Sandy \\
\hline
\end{tabular}


The chemical analysis shows few differences between the soil composition of the two blocks. Nevertheless, block 102 can be considered slightly more fertile than block 155 due to the availability of Ca, $\mathrm{Mg}$ and base saturation (V\%).

Soil from block 155 was composed of $84.0 \%$ sand, classifying it as a sandy soil, while block102 had $55.6 \%$ clay and was classified as clayey soil. Due to this difference in composition, the comparisons discussed here in will treat block 102 (T102) as clay soil and block 155 (T155) as sandy soil. Considering both the chemical and physical characteristics of the soil, it is possible to affirm that the T102 is a potentially better site for the development of the clones.

The experiments designed in blocks with one tree per plot, with a total of 130 clones (treatments), repeated in 20 blocks. For the soil preparation, lime was applied across the whole planting area at a dose of $2000 \mathrm{~kg}$.ha $\mathrm{h}^{-1}$ and gypsum at $1000 \mathrm{~kg} \cdot \mathrm{ha}^{-1}$. The area was graded, followed by subsoiling to an approximate depth of $60 \mathrm{~cm}$, and a simple superphosphate fertilizer was applied in the fur row sand in a continuous line, at a dose of $500 \mathrm{~kg} . \mathrm{ha}^{-1}$. The planting was done in a $4 \times 3 \mathrm{~m}$ spacing, which follows the procedures of the company, and fertilizing of the trees was conducted 10 days after planting with $85 \mathrm{~kg}$.ha- ${ }^{-1} \mathrm{NPK}$ 06-30-06 + micronutrients placed in lateral holes. Fertilization was again conducted at 90 days with NPK 20-00-20, at a dose of $85 \mathrm{~kg}^{-h^{-1}}$, and at 12 months with $\mathrm{KCl}+1 \% \mathrm{~B}$, at a dose of $150 \mathrm{~kg} \cdot \mathrm{ha}^{-1}$, both in lateral holes.

After two years, annual evaluations of survival were conducted, and circumference at breast height $(\mathrm{CBH}$ in $\mathrm{cm}$ at $1.30 \mathrm{~m}$ from the soil) and total height $(\mathrm{H}, \mathrm{m})$ of all trees in the experiment were measured.

To evaluate the clones, the wood volume $(\mathrm{V})$ by tree was estimated with the equation (1):

$$
\text { (1) } \mathrm{V}\left(\mathrm{m}^{3}\right)=\frac{\pi(D B H)^{2} f f H}{40000} \text {, }
$$

where: $\mathrm{V}=$ volume of the tree in cubic meters; $\mathrm{DBH}=$ diameter at breast height $(1.30 \mathrm{~m}$ from the soil $)$, in centimeters; $\mathrm{H}=$ total height of the trees in meters; $\mathrm{ff}=0.5$ (form factor).

Estimates of the variance components and genetic parameters were obtained through the Selegen statistical software using the procedure REML/BLUP, as proposed by Resende (2007).

For the independent analysis of each experiment, the mathematical model number 20 was used, delineated in complete blocks with evaluation at one site and single observation per plot (RESENDE, 2007), represented by the statistical model: $y=\boldsymbol{X} r+\mathbf{Z} g+e$, where: $y=$ vector of data; $r=$ vector of effects of repetition (assumed as steady) added to the general average; $g=$ vector of the genotypical effects (assumed as random); $e=$ vector of errors or waste (random); and $\mathbf{X}$ and $\mathbf{Z}=$ matrices of vector incidence.

The genotypic variance $\left(\hat{\sigma}_{g}^{2}\right)$, between plant residual variance $\left(\hat{\sigma}_{e}^{2}\right)$, and individual phenotype variance $\left(\hat{\sigma}_{f}^{2}\right)$ were determined by expressions $(2,3$, and 4$)$ :

$$
\begin{array}{lll}
\text { (2) } \hat{\sigma}_{g}^{2}=\left[\hat{g}^{\prime} \hat{g}+\hat{\sigma}_{e}^{2} \operatorname{tr}\left(C^{22}\right) / q\right] & \text { (3) } \hat{\sigma}_{e}^{2}=\left[y^{\prime} y-\hat{r}^{\prime} X^{\prime} y-\hat{g}^{\prime} Z^{\prime} y\right] /[N-r(x)] \quad \text { (4) } \hat{\sigma}_{f}^{2}=\hat{\sigma}_{g}^{2}+\hat{\sigma}_{e}^{2},
\end{array}
$$

where: $\mathrm{C}^{22}=$ the inverse of the matrix of coefficients of mixed model equations; $\operatorname{tr}=$ matrix operator; $r(x)=$ matrix station $X ; N, q$, and $s=$ total number of data, of clones, and genotype $\mathrm{x}$ environment combinations, respectively.

Broad sense heritability individually for each single-tree plot $\left(\hat{h}_{g}^{2}\right)$ or the total genotypic effects, average clone heritability $\left(\hat{h}_{m}^{2}\right)$ assuming complete survival, and clone selection precision $\left(\hat{r}_{a a}\right)$ assuming complete survival, were determined by the expressions $(5,6$, and 7$)$ :

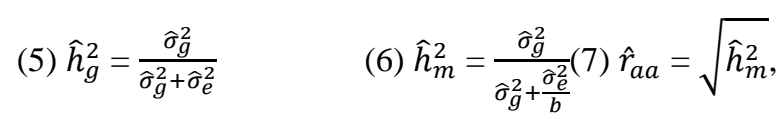

where: $b=$ number of blocks.

The coefficients of genotypic variance $\left(\widehat{C V}_{g i} \%\right)$, of residual variance $\left(\widehat{C V}_{e} \%\right)$, and of relative variance $\left(\widehat{C V}_{r} \%\right)$ were determined by expressions $(8,9$, and 10$)$ :
(8) $\widehat{C V}_{g} \%=\frac{\sqrt{\widehat{\sigma}_{g}^{2}}}{m} x 100$
(9) $\widehat{C V}_{e} \%=\frac{\sqrt{\widehat{\sigma}_{e}^{2}}}{m} x 100$
(10) $\widehat{C V}_{r} \%=\frac{\widehat{C V}_{g i}}{\widehat{C V}_{e}}$

where: $m=$ average of the evaluated trait. 
For the joint analysis of the experiments, the mathematical model number 54 was used, with the harmonic mean of the relative performance of genetic values MHPRVG method, delineated in complete blocks with various locations and one observation per plot (RESENDE, 2007), represented by the statistical model: $y=\boldsymbol{X} r+\mathbf{Z} g+$ W $g e+e$, where: $y=$ vector of data; $r=$ vector of the effects of repetition (assumed as steady) added to the general averages; $g=$ vector of the genotypical effects (assumed as random); $g e=$ vector of the genotype $\mathrm{x}$ environment interaction effects (random); $e=$ vector of error or waste (random); and $\mathbf{X}, \mathbf{Z}$ and $\mathbf{W}=$ matrices of incidence of vectors.

The genotypical variance $\left(\hat{\sigma}_{g}^{2}\right)$, variance of the genotype $\mathrm{x}$ environment interaction $\left(\hat{\sigma}_{g e}^{2}\right)$, between plant residual variance $\left(\hat{\sigma}_{e}^{2}\right)$, and individual phenotypic variance $\left(\sigma_{f}^{2}\right)$ were determined by the expressions $(11,12,13$, and 14):

$$
\begin{aligned}
& \text { (11) } \hat{\sigma}_{g}^{2}=\left[\hat{g}^{\prime} \hat{g}+\hat{\sigma}_{e}^{2} \operatorname{tr}\left(C^{22}\right) / q\right] \\
& \text { (12) } \hat{\sigma}_{g e}^{2}=\left[\widehat{g e} \cdot \widehat{g e}+\hat{\sigma}_{g}^{2} \operatorname{tr}\left(C^{33}\right) / s\right] \\
& \text { (13) } \hat{\sigma}_{e}^{2}=\left[y^{\prime} y-\widehat{b}^{\prime} X^{\prime} y-\hat{g}^{\prime} Z^{\prime} y-\widehat{g e} W^{\prime} y\right] /[N-r(x)] \\
& \text { (14) } \hat{\sigma}_{f}^{2}=\hat{\sigma}_{g}^{2}+\hat{\sigma}_{g e}^{2}+\hat{\sigma}_{e}^{2} \text {, }
\end{aligned}
$$

where: $\mathrm{C}^{22}$ and $\mathrm{C}^{33}=$ the inverse of the matrix of coefficients of mixed model equations; $t r=$ matrix operator; $r(x)=$ matrix station $X$; and $N, q$, and $s=$ total number of data, of clones, and genotype $\mathrm{x}$ environment combinations, respectively.

Broad sense heritability of the individual single-tree plots $\left(\hat{h}_{g}^{2}\right)$ or the total effects of genotypes $\left(\hat{h}_{m}^{2}\right)$ assuming complete survival, and accuracy in the selection of the clones $\left(\hat{r}_{a a}\right)$ assuming complete survival were determined by the expressions $(15,16$, and 17$)$ :

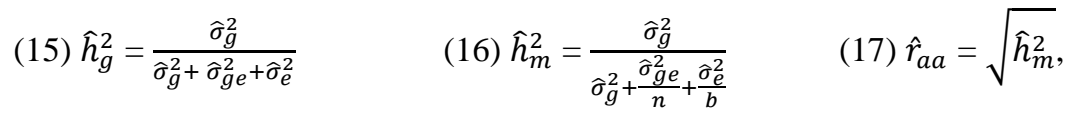

where: $n=$ number of environments; and $b=$ number of blocks.

The coefficient that determines the genotype x environment interaction effects $\left(C_{g e}^{2}\right)$ and the genotypic correlation between the output of the clones in various environments $\left(\hat{r}_{\text {gloc }}\right)$ were determined by expressions $(18$ and 19):

$$
\text { (18) } \hat{C}_{g e}^{2}=\frac{\widehat{\sigma}_{g e}^{2}}{\hat{\sigma}_{g}^{2}+\widehat{\sigma}_{g e}^{2}+\widehat{\sigma}_{e}^{2}} \quad \text { (19) } \hat{r}_{g l o c}=\frac{\widehat{\sigma}_{g}^{2}}{\hat{\sigma}_{g}^{2}+\widehat{\sigma}_{g e}^{2}}
$$

The coefficients of genotypic variance $\left(\widehat{C V}_{g} \%\right)$, of residual variance, and of relative variance are determined by expressions $(8,9$, and 10$)$, as described in the above model.

\section{RESULTS}

The mortality rate increased throughout tree development (Figure 2), reaching $46.4 \%$ in the environment with clay soil and $49.3 \%$ in the sandy soil environment.

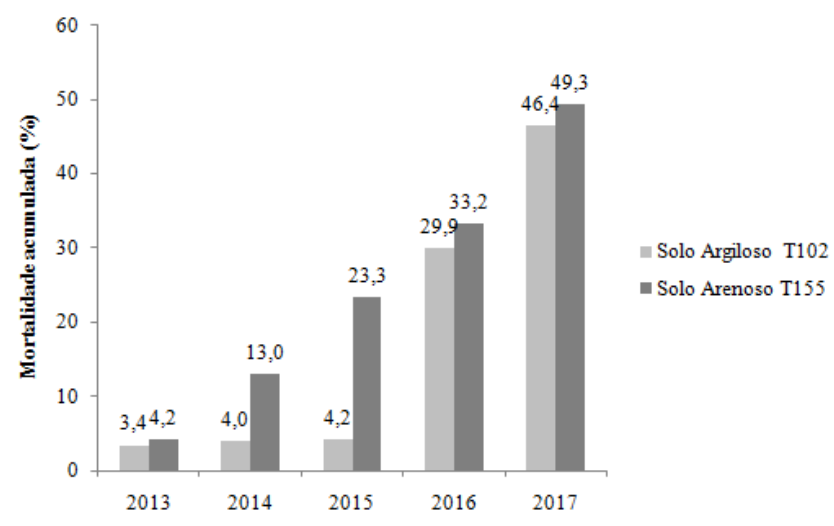

FLORESTA, Curitiba, PR, v. 50, n. 2, p. 1267 - 1278, abr/jun 2020.

Furlan, R. A. et.al.

ISSN eletrônico 1982-4688 
Figura 2. Mortalidade acumulada ao longo dos anos (em \%) das árvores dos testes clonais de Eucalyptus spp., localizados no município de Grajaú, estado do Maranhão.

Figure 2. Accumulated mortality over the study years (in \%) of Eucalyptus spp. trees in clonal tests located in Grajaú, Maranhão State.

For the clay soil environment, the residual variance $\left(\hat{\sigma}_{e}^{2}\right)$ was superior to the genotypic variance $\left(\hat{\sigma}_{g}^{2}\right)$ for all three evaluated traits, while for the sandy soil the genotypic variance $\left(\hat{\sigma}_{g}^{2}\right)$ was superior to the residual $\left(\hat{\sigma}_{e}^{2}\right)$, also for all traits (Table 3). Variance components different from zero, as estimated, indicate that the effect of the genotypes (clones) was significant for all evaluated traits.

Tabela 3. Variâncias e parâmetros genéticos estimados aos seis anos para os caracteres diâmetro à altura do peito, altura e volume para análise individual dos testes clonais de Eucalyptus spp., localizados no município de Grajaú, estado do Maranhão.

Table 3. Variance and genetic parameters estimated at six years of age for diameter at breast height (DBH), height, and volume (VOL) for individual analysis of Eucalyptus spp. clonal tests, located in Grajaú, Maranhão State.

\begin{tabular}{|c|c|c|c|}
\hline Trait & $\begin{array}{c}\text { Genetic } \\
\text { Parameter }\end{array}$ & $\begin{array}{c}\text { Location } \\
\text { Clay Soil T102 }\end{array}$ & Sandy Soil T155 \\
\hline & & 6 years & 6 years \\
\hline \multirow{11}{*}{$\begin{array}{l}\text { DBH } \\
(\mathbf{c m})\end{array}$} & $\hat{\sigma}_{g}^{2}$ & 3.25 & 8.06 \\
\hline & $\hat{\sigma}_{e}^{2}$ & 4.68 & 5.34 \\
\hline & $\hat{\sigma}_{f}^{2}$ & 7.93 & 13.40 \\
\hline & $\hat{h}_{g}^{2}$ & 0.41 & 0.60 \\
\hline & $\hat{h}_{m}^{2}$ & 0.93 & 0.97 \\
\hline & $\hat{r}_{a a}$ & 0.97 & 0.98 \\
\hline & $\widehat{C V}_{g} \%$ & 12.42 & 20.01 \\
\hline & $\widehat{C V}_{e} \%$ & 14.90 & 16.29 \\
\hline & $\widehat{C V}_{r}$ & 0.83 & 1.23 \\
\hline & $\operatorname{LRT}\left(\chi^{2}\right)$ & $513.91 * *$ & $1003.96 * *$ \\
\hline & average & 14.52 & 14.18 \\
\hline \multirow{11}{*}{$\begin{array}{l}\text { HEIGHT } \\
\quad(\mathrm{m})\end{array}$} & $\hat{\sigma}_{g}^{2}$ & 2.3 & 6.4 \\
\hline & $\hat{\sigma}_{e}^{2}$ & 4.3 & 5.3 \\
\hline & $\hat{\sigma}_{f}^{2}$ & 6.6 & 11.6 \\
\hline & $\widehat{h}_{g}^{2}$ & 0.3 & 0.6 \\
\hline & $\hat{h}_{m}^{2}$ & 0.9 & 0.9 \\
\hline & $\hat{r}_{a a}$ & 0.9 & 0.9 \\
\hline & $\widehat{C V}_{g} \%$ & 7.7 & 13.90 \\
\hline & $\widehat{C V}_{e} \%$ & 10.7 & 12.65 \\
\hline & $\widehat{\widehat{C V}}_{r}$ & 0.7 & 1.01 \\
\hline & $\operatorname{LRT}\left(\chi^{2}\right)$ & $345.9 * *$ & $707.7 * *$ \\
\hline & average & 19.4 & 18.2 \\
\hline \multirow{11}{*}{$\begin{array}{l}\text { VOL } \\
\left(\mathbf{m}^{3}\right)\end{array}$} & $\hat{\sigma}_{g}^{2}$ & 0.0030 & 0.0086 \\
\hline & $\hat{\sigma}_{e}^{2}$ & 0.0039 & 0.0052 \\
\hline & $\hat{\sigma}_{f}^{2}$ & 0.0069 & 0.0139 \\
\hline & $\widehat{h}_{g}^{2}$ & 0.4354 & 0.6218 \\
\hline & $\hat{h}_{m}^{2}$ & 0.9391 & 0.9705 \\
\hline & $\hat{r}_{a a}$ & 0.9691 & 0.9851 \\
\hline & $\widehat{C V}_{g} \%$ & 31.6805 & 56.8090 \\
\hline & $\widehat{C V}_{e} \%$ & 36.0767 & 44.3026 \\
\hline & $\widehat{C V}_{r}$ & 0.8781 & 1.2823 \\
\hline & $\operatorname{LRT}\left(\chi^{2}\right)$ & $585.0000 * *$ & $1109.6667 * *$ \\
\hline & average & 0.1728 & 0.1633 \\
\hline
\end{tabular}


$\hat{\sigma}_{g}^{2}=$ variância genotípica; $\hat{\sigma}_{e}^{2}=$ variância residual; $\hat{\sigma}_{f}^{2}=$ variância fenotípica individual; $\hat{h}_{g}^{2}=$ herdabilidade de parcelas individuais no sentido amplo, ou dos efeitos genotípicos totais; $\hat{h}_{m}^{2}=$ herdabilidade média do genótipo; $\hat{r}_{a a}=$ acurácia de seleção dos genótipos; $\widehat{C V}_{g}=$ coeficiente de variação genotípica; $\widehat{C V}_{e}=$ coeficiente de variação residual ou experimental; $\widehat{C V}_{r}=$ coeficiente de variação relativa; $\mathrm{LRT}=\chi^{2}=$ teste da razão de verossimilhança. $\chi^{2}$ tabelado: $3,84(*)$ e $6,63(* *)$, respectivamente para os níveis de significância de $5 \%$ e $1 \%$, a 1 grau de liberdade. $\hat{\sigma}_{g}^{2}=$ genotypic variance; $\hat{\sigma}_{e}^{2}=$ residual variance; $\hat{\sigma}_{f}^{2}=$ individual phenotypic variance; $\hat{h}_{g}^{2}=$ broad sense heritability of individual plots or the total genotypic effects; $\hat{h}_{m}^{2}=$ average clone heritability; $\hat{r}_{a a}=$ genotype selection accuracy; $\widehat{C V}_{g}=$ coefficient of genotypic variance; $\widehat{C V}_{e}=$ coefficient of residual or experimental variance; $\widehat{C V}_{r}=$ coefficient of relative variance; LRT $=\chi^{2}=$ likelihood ratio test. $\chi^{2}$ tabulated: $3.84(*)$ and $6.63(* *)$, respectively for levels of significance of $5 \%$ and $1 \%$, with 1 degree of freedom.

The genetic parameters estimated individually for the traits DBH, height and volume at six years of age in clay and sandy soils, were significant to one degree of freedom by the Likelihood Radio Test (LRT; $\chi^{2}$ ). The highest obtained value for $\chi^{2}(1109,6667)$ was for volume in the sandy soil environment (Table 3$)$.

The broad sense heritabilities of individual tree plots or the total genotypic effects $\left(\hat{h}_{g}^{2}\right)$, evaluated individually for the experiments presented much higher values for all traits in the sandy soil than the clay soil.

The estimates of the average clone heritability $\left(\hat{h}_{m}^{2}\right)$ follow the same pattern of the heritabilities of the individual plots, with increases for traits of height, DBH and volume, in both soils (Table 3).

The estimated values for the accuracy $\left(\hat{r}_{a a}\right)$ of all the evaluated traits and in both experiments were consistently above to 0.96 (Table 3 ).

Coefficients of genetic variance $\left(\widehat{C V}_{g} \%\right)$ follow a similar pattern to height, DBH and volume, in both soils. For volume, the $\widehat{C V}_{g i} \%$ was 31.68 and $56.81 \%$ for the clay and sandy soil, respectively (Table 3 ).

Values of experimental variance coefficients $\left(\widehat{C V}_{e} \%\right)$ estimated for volume were $36.08 \%$ in clay soil and $44.30 \%$ in sandy soil.

The values obtained for the coefficient of relative variance $\left(\widehat{C V}_{r}\right)$ were consistently higher in the sandy soil than the clay soil for all evaluated traits. For both, the results for volume presented the highest value at 0.88 in clay soil and 1.28 in sandy soil.

For the joint analysis of the experiments the harmonic mean of the relative performance of genetic values method (MHPRVG) was used and informed by BLUP.

The deviance analysis was conducted for genotypes (clones) and environments for all evaluated traits (Table 4), and the estimated values were significant.

Tabela 4: Análise de deviance $\left(\chi^{2}\right)$ para os caracteres diâmetro à altura do peito, altura e volume para a análise conjunta dos testes clonais de Eucalyptus spp., localizados no município de Grajaú, estado do Maranhão.

Table 4: Deviance analysis $\left(\chi^{2}\right)$ for diameter at breast height (DBH), height, and volume (VOL) for the joint analysis of Eucalyptus spp. clonal tests located in Grajaú, Maranhão State.

\begin{tabular}{cccc}
\hline Effect & \multicolumn{3}{c}{ Trait } \\
\hline & DBH $(\mathbf{c m})$ & HEIGHT(m) & VOL $\left(\mathbf{m}^{3}\right)$ \\
& LRT $\left(\chi^{2}\right)$ & LRT $\left(\chi^{2}\right)$ & LRT $\left(\chi^{2}\right)$ \\
\hline Clones & $80.26^{* *}$ & $43.63^{* *}$ & $86.06^{* *}$ \\
Clones x locations & $147.78^{* *}$ & $156.79^{* *}$ & $180.95^{* *}$ \\
\hline
\end{tabular}

LRT $\left(\chi^{2}\right)=$ teste da razão de verossimilhança. $\chi^{2}$ tabelado: $3,84(*)$ e $6,63(* *)$, respectivamente para os níveis de significância de $5 \%$ e $1 \%$, a 1 grau de liberdade.

LRT $\left(\chi^{2}\right)=$ likelihood ratio test. $\chi^{2}$ tabulated: $3.84\left(^{*}\right)$ and $6.63(* *)$, respectively for the levels of significance at $5 \%$ and $1 \%$, with 1 degree of freedom.

The LRT $\left(\chi^{2}\right)$ values were always higher for the genotype $\mathrm{x}$ environment interaction effects than the values between clones for all traits, and volume for the genotype $\mathrm{x}$ environment interaction presented the highest value.

For the joint analysis of the data, the phenotypic variance $\left(\hat{\sigma}_{f}^{2}\right)$ was more influenced by the genotypic $\left(\hat{\sigma}_{g}^{2}\right)$ and experimental variance $\left(\hat{\sigma}_{e}^{2}\right)$ than the variance of the genotype $\mathrm{x}$ environment interaction $\left(\hat{\sigma}_{g e}^{2}\right)$ (Table 5).

Although it presented low variation, the coefficient of determination of the genotype $\mathrm{x}$ environment interaction $\left(\hat{C}_{i n t}^{2}\right)$ was increasing for the traits DBH, volume and height $(0.11,0.2$, and 0.1117 , respectively. (Table $5)$.

The genotypic correlation between environments $\left(\hat{r}_{\text {gloc }}\right)$ was high, with values for height close to 0.7 and above 0.8 for DBH and volume (Table 5).

FLORESTA, Curitiba, PR, v. 50, n. 2, p. 1267 - 1278, abr/jun 2020.

Furlan, R. A. et.al.

ISSN eletrônico 1982-4688

DOI: $10.5380 /$ rf.v50 i2. 62524 
Tabela 5: Variâncias e parâmetros genéticos estimadas aos seis anos, para os caracteres diâmetro à altura do peito, altura e volume, para a análise conjunta, dos testes clonais de Eucalyptus spp., localizados no município de Grajaú, estado do Maranhão.

Table5: Variance and genetic parameters estimated at six years of age for diameter at breast height (DBH), height and volume (VOL), for the joint analysis of Eucalyptus spp. clonal tests located in Grajaú, Maranhão State.

\begin{tabular}{cccc}
\hline $\begin{array}{l}\text { Variance/ } \\
\text { Genetic Parameter }\end{array}$ & DBH (cm) & HEIGHT(m) & VOL $\left(\mathbf{m}^{\mathbf{3}}\right)$ \\
\hline$\hat{\sigma}_{g}^{2}$ & 4.58 & 2.9 & 0.0048 \\
$\hat{\sigma}_{g e}^{2}$ & 1.18 & 1.4 & 0.0012 \\
$\hat{\sigma}_{e}^{2}$ & 5.00 & 4.8 & 0.0045 \\
$\hat{\sigma}_{f}^{2}$ & 10.76 & 9.1 & 0.0105 \\
$\hat{h}_{m}^{2}$ & 0.86 & 0.8 & 0.8683 \\
$\hat{C}_{\text {int }}^{2}$ & 0.11 & 0.2 & 0.1117 \\
$\hat{r}_{a a}$ & 0.93 & 0.8 & 0.9318 \\
$\hat{r}_{g l o c}$ & 0.80 & 0.7 & 0.8032 \\
$\widehat{C V}_{g} \%$ & 14.87 & 9.0 & 40.8866 \\
$\widehat{C V}_{e} \%$ & 15.54 & 11.7 & 39.7999 \\
$\widehat{C V}_{r}$ & 0.96 & 0.8 & 1.0273 \\
average & $\mathbf{1 4 . 3 9}$ & $\mathbf{1 8 . 7}$ & $\mathbf{0 . 1 6 9 2}$ \\
\hline
\end{tabular}

$\hat{\sigma}_{g}^{2}=$ variância genotípica; $\hat{\sigma}_{g e}^{2}=$ variância da interação genótipo x ambiente $(\mathrm{G} \times \mathrm{E}) ; \hat{\sigma}_{e}^{2}=$ variância residual; $\hat{\sigma}_{f}^{2}=$ variância fenotípica individual; $\hat{h}_{g}^{2}=$ herdabilidade parcelas individuais no sentido amplo, ou dos efeitos genotípicos totais; $\hat{h}_{m}^{2}=$ herdabilidade média do genótipo; $\hat{C}_{i n t}^{2}=$ coeficiente de determinação dos efeitos da interação genótipo x ambiente; $\hat{r}_{a a}=$ acurácia de seleção dos genótipos; $\hat{r}_{g l o c}=$ correlação genotípica entre os ambientes; $\widehat{C V}_{g}=$ coeficiente de variação genotípica; $\widehat{C V}_{e}=$ coeficiente de variação residual ou experimental; $\widehat{C V}_{r}=$ coeficiente de variação relativa; LRT $=\chi^{2}=$ teste da razão de verossimilhança.

$\hat{\sigma}_{g}^{2}=$ genotypic variance; $\hat{\sigma}_{g e}^{2}=$ variance of genotype $\mathrm{x}$ environment $(\mathrm{GxE})$ interaction; $\hat{\sigma}_{e}^{2}=$ residual variance; $\hat{\sigma}_{f}^{2}=$ individual phenotypic variance; $\widehat{h}_{g}^{2}=$ broad sense heritability of single-tree plots or the total genotypic effects; $\hat{h}_{m}^{2}=$ average clone heritability; $\widehat{C}_{i n t}^{2}=$ coeficient of determination of GxE interaction effects; $\widehat{r}_{a a}=$ genotype selection accuracy; $\hat{r}_{g l o c}=$ genotypic correlation between environments; $\widehat{C V}_{g}=$ coefficient of genotypic variance; $\widehat{C V}_{e}=$ coefficient of residual or experimental variance; $\widehat{C V}_{r}=$ coefficient of relative variance; LRT $=\chi^{2}=$ likelihood ratio test.

\section{DISCUSSION}

The mortality rate (Figure 2) in the clay soil environment was consistently lower in relation the sandy soil, demonstrating the superior quality of the site with clay soils. Between the years 2013 and 2015 in the clay soil environment, there was a slight increase in dead trees. However, with the drought in 2015, where the accumulated precipitation was $650 \mathrm{~mm}$, this rate increased significantly. In contrast, in the sandy soil environment, the mortality increased steadily over the years.

Phenotypic variances resulted in a greater amount of genotypic variance in relation to the environment, suggesting high genetic variability among the tested clones, particularly considering volume. All estimated variances were greater in the clay soil than the sandy soil environment, especially the genotypic variances. These results indicate a greater influence of the genetic factor on the expression of the phenotype in the sandy soil conditions.

In an experiment installed in the south of Bahia, Garcia and Nogueira (2005) assessed the selection for volume of E. grandis and E. pellita clones and the hybrid E. urograndis at 7 years of age. In comparing the estimated variances of their study with those obtained here in, the genotypic variance $\left(\hat{\sigma}_{g}^{2}\right)$ of 0.0128 was greater than that estimated for both soils, as well as the phenotypic variance $\left(\hat{\sigma}_{f}^{2}\right)$ of 0.0276 and the residual variance $\left(\hat{\sigma}_{e}^{2}\right)$ of 0.0112. However, the greater number of clones used in that study (312 in total) has an influence on variability. 
Variance values quite superior to what was found herein were obtained by Osorio et al. (2003) for volume at 6 years of age in clonal tests of $E$. grandis in Colombia. They estimated the genotypic variance $\left(\hat{\sigma}_{g}^{2}\right)$ at 0.2170 and the residual variance $\left(\hat{\sigma}_{e}^{2}\right)$ of 0.6530 . Although the number of studied clones was lower ( 65 clones), the analysis included three different environmental conditions, which can increase variance estimates.

In relation to the genetic parameters estimated and tested by the Likelihood Radio Test (LRT; $\chi^{2}$ ), the highest value obtained was for volume in sandy soil $(1109,6667)$, reinforcing the possibility presented above of a greater influence of genetics in the expression of this phenotypic trait under sandy soil conditions.

Estimates of heritability are very important for breeding programs because they enable the quantification of the available genetic variability of a population and determine the relative genetic and environmental variations.

The broad sense heritabilities of single-tree plots $\left(\hat{h}_{g}^{2}\right)$ evaluated individually for each experiment, presented much greater values in the sandy soil environment compared to the clay soil for all traits. Again, this suggests that the environmental variation has a greater influence on the phenotypes in the clay soil, as the genetic effects are more predominant in the sandy soil. The estimated values of $\hat{h}_{g}^{2}$ corroborate those observed by Garcia and Nogueira (2005) in the selection of clones in the south of Bahia, where the heritability of single-tree plots $\left(\hat{h}_{g}^{2}\right)$ for volume was 0.46 .

The clone average heritability $\left(\hat{h}_{m}^{2}\right)$ (Table 3 ) was greater than 0.9 , indicating the possibility to maintain gains in the selection of better clones. In research on clones, values of $\hat{h}_{m}^{2}$ above 0.75 are common, mainly for DBH and volume (GARCIA; NOGUEIRA, 2005; BELTRAME et al., 2012; SANTOS et al., 2015).

Estimated values for accuracy $\left(\hat{r}_{a a}\right)$ were greater than 0.96 for all evaluated traits and in both experiments. This attests to the reliability of the experimental design and the data obtained (Table 3), as well as the certainty of the selection of better clones. As with the high $\hat{h}_{m}^{2}$, elevated values of $\hat{r}_{a a}$ are common in experiments on eucalypt clones, as the parameter $\hat{r}_{a a}$ is essentially derived from $\hat{h}_{m}^{2}$. Values greater than 0.85 have been reported by various authors for DBH and volume (GARCIA; NOGUEIRA, 2005; BELTRAME et al., 2012; ROSADO et al., 2012; MORAES et al., 2014; SANTOS et al., 2015; TAMBARUSSI et al., 2017).

The coefficient of genetic variation $\left(\widehat{C V}_{g} \%\right)$ for these experiments expresses a general average of the amount of genetic variation between clones. The estimated $\widehat{C V}_{g i} \%$ values followed a pattern of increase for the traits of height, $\mathrm{DBH}$, and volume in both soils. Volume is a quantitative trait dependent on the other variables (DBH and height) and is highly influenced by the environment.

The values of $\widehat{C V}_{g} \%$ obtained for volume were 31.68 and $56.81 \%$ for the clay and sandy soil environments, respectively, showing good genetic variation between clones and indicating a potential for selection of the best in terms of growth in volume (Table 3).

The coefficient of experimental variation $\left(\widehat{C V}_{e} \%\right)$ of $36.08 \%$ in the clay soil environment is considered medium, indicating good experimental precision, and $44.30 \%$ in sandy soil which indicates regular precision. The higher rate of mortality on sandy soil certainly contributes to the increase in this coefficient. According to Garcia (1989), values of $\widehat{C V}_{e} \%$ for volume in genetic tests of Eucalyptus can be considered medium between 20.5 and $38.6 \%$ and high between 38.7 and $47.7 \%$. Under field conditions, it is common to obtain superior values for forest species than those observed for other cultivars.

The coefficient of relative variation $\left(\widehat{C V}_{r}\right.$ or $\left.\hat{b}\right)$, also denominated variation index, is another important genetic parameter for tree improvement. According to Vencovsky (1987), the higher the value of $\widehat{C V}_{r}$, the greater the genetic control over the traits and lower the influence of environmental factors on the phenotype. From the values of $\widehat{C V}_{r}$ obtained in both environments, the volume presented the highest value at 0.88 in the clay soil and 1.28 in the sandy soil. These values are considered high; thus, selection for volume would be effective from a genetic point of view (VENCOVSKY; BARRIGA; 1992).

For the joint analysis of the experiments the MHPRVG method provides the harmonic means of the relative performance of genetic values and is based on BLUP. According to Castro et al. (2016), REML/BLUP efficiently selects families, progeny, and individuals, even in the presence of unbalanced data (a common event in eucalypt tests), and has also been used to identify Eucalyptus clones broadly adapted to a range of environments, specifically through the evaluation of the effect of different environmental conditions on clones (genotype $\mathrm{x}$ environment interaction).

The significant estimated deviance values for all evaluated traits (Table 4) show that there is genetic variability among the tested clones and the possibility of gains with selection.

FLORESTA, Curitiba, PR, v. 50, n. 2, p. 1267 - 1278, abr/jun 2020.

Furlan, R. A. et.al.

ISSN eletrônico 1982-4688 
For the genotype $\mathrm{x}$ environment interaction, there is a differential behavior among clones in each environment. The LRT $\left(\chi^{2}\right)$ values were consistently higher for the genotype $\mathrm{x}$ environment interaction than between clones for all traits, indicating the difference between clones in the environments. The genotype $\mathrm{x}$ environment interaction had the greatest effect on volume.

The coefficient of determination of the genotype $\mathrm{x}$ environment interaction $\left(\hat{C}_{i n t}^{2}\right)$ presented low levels of variance, with height being the most affected (Table 5).

The genotypic correlation between the environments $\left(\hat{r}_{\text {gloc }}\right)$ was high. According to Vencovsky and Barriga (1992), high values of genotypic correlation $\left(\hat{r}_{\text {gloc }}\right)$ indicate that the interaction between the clones and the environment is simple; in other words, the relative ranking of the genotypes is minimally altered by the effects of environments. A simple interaction occurs when the genotypes present different behaviors in the different types of environments, but the classification of productivity of the genotypes is not altered among environments (MORAIS et al., 2010; SANTOS et al., 2015).

The heritabilities of the total genotypic effects $\left(\hat{h}_{g}^{2}\right)$ and the average clone heritabilities $\left(\hat{h}_{m}^{2}\right)$ estimated through the joint analysis (Table 5) were close to those estimated for the clay soil in the individual analysis (Table 3 ). The values of average heritability $\left(\hat{h}_{m}^{2}\right)$ of 0.86 and selection accuracy $\left(\hat{r}_{a a}\right)$ of 0.93 for DBH and volume (Table 5) indicate reliability of the data, experimental precision, and certainty in the ranking of the best clones. As noted for the individual analysis, high values of $\hat{h}_{m}^{2}$ and $\hat{r}_{a a}$ are common in studies on Eucalyptus clones, even in the evaluation of different environments. Rosado et al. (2012) and Santos et al. (2015) present similar results to those observed here in, although they occurred under distinct environmental conditions.

The coefficient of genotypic variance $\left(\widehat{C V}_{g i}\right)$ for the joint analysis again indicates significant potential for the selection of the best clones for growth in volume, while the coefficients of experimental variation $\left(\widehat{C V}_{e}\right)$ are considered medium and indicate good experimental precision (Table 5).

\section{CONCLUSION}

- (i) The studied Eucalyptus clones present high genetic variability for drought tolerance, the coefficients of heritability had a high magnitude for the studied traits, and the genetic and phenotypic correlations were high and positive. This enables us to conclude that there is a good chance of success in selection and genetic gains.

- (ii) Genotype x environment interaction occurred for the clones and the type of interaction is simple.

\section{AKNOWLEDGEMENTS}

The authors thank the company Gusa Nordeste S. A., member of Grupo Ferroeste, especially the Director Ricardo Nascimento, the Coordinator Wallas Silva and the Supervisor Flávio Mendes for making the data available. Professor Evandro Vagner Tambarussi, Ph.D. was supported by a National Council of Technological and Scientific Development (CNPq n. 304899/2019-4) research fellowship.

\section{BIBLIOGRAPHY}

ALVARES, C. A.; STAPE, J. L.; SENTELHAS, P. C.; GONÇALVES, J. L. M.; SPAROVEK, G. Köppen's climate classification map for Brazil. Meteorologische Zeitschrift, Stuttgart, v. 22, n. 6, p. 711-728, 2013.

ANDRADE, M. C.; SIQUEIRA, L.; ODA, S., MEDEIROS, R. N.; TAMBARUSSI, E. V. Genetic variability in progenies of Eucalyptus grandis and Eucalyptus urophylla for tolerance to hydric deficit. Floresta, Curitiba, v. 48, n. 4, p. 543-552, 2018.

BELTRAME, R.; BISOGNIN, D. A.; MATtOS, B. D.; CARGNELUTTI FILHO, A.; HASELEIN, C. R.; GATTO, D. A.; SANTOS, G. A. Desempenho silvicultural e seleção precoce de clones de híbridos de eucalipto. Pesquisa Agropecuária Brasileira, Brasília, v. 47, n. 6, p. 791-796, 2012.

CASTRO, C. A. O.; RESENDE, R. T.; BHERING, L. L.; CRUZ, C. D. Brief history of Eucalyptus breeding in Brazil under perspective of biometric advances. Ciência Rural, Santa Maria, v.46, n.9, 2016.

EMPRESA BRASILEIRA DE PESQUISA AGROPECUÁRIA - EMBRAPA. Sistema brasileiro de classificação de solos. 3.ed. Brasília, 2013. 353 p. 
ENGEL, M. L.; HIGA, A. R.; ANDREJOW, G. P.; FLORES JUNIOR, P. C.; SOARES, I. D. Genetic gain from different selection methods in Eucalyptus macarthurii progenies in different environments. Cerne, Lavras, v.22, p.299-308, 2016.

GARCIA, C. H. Tabelas para classificação do coeficiente de variação. Piracicaba: IPEF, 1989. 12p. (Circular Técnica, 171).

GARCIA, C. H.; NOGUEIRA, M. C. S. Utilização da metodologia REML/BLUP na seleção de clones de eucalipto. Scientia Forestalis, Piracicaba, n. 68, p. 107-112, ago. 2005.

INDÚSTRIA BRASILEIRA DE ÁRVORES. Relatório IBÁ 2017. Brasília, 2017. 80 p. Disponível em: <http://iba.org/pt/biblioteca-iba/publicacoes>. Acesso em: 25/04/2018.

INSTITUTO NACIONAL DE METEREOLOGIA. Disponível em: <http://www.inmet.gov.br/portal/index.php?r=bdmep/bdmep>. Acesso em: 16/01/2018.

MORAES, C. B.; FREITAS, T. C. M.;PIERONI, G. B.; RESENDE, M. D. V.; ZIMBACK, L.; MORI, E. S. Estimativas de parâmetros genéticos para seleção precoce de clones de Eucalyptus para região com ocorrência de geadas.ScientiaForestalis, Piracicaba, p. 219-227, 2014.

MORAIS, E.; ZANATTO, A. C. S.; FREITAS, M. L. M.; MORAES, M. L. T.; SEBBENN, A. M. Variação genética, interação genótipo solo e ganhos na seleção em teste de progênies de Corymbia citriodora Hook em Luiz Antonio, São Paulo. ScientiaForestalis, Piracicaba, v. 38, n. 85, p. 11-18, 2010.

OliveIRA, T. W. G.; PAUlA, R. C.; MORAES, M. L. T. .; ALVARES, C. A., MiRANDA, A. C.; SILVA, P. H. M. Stability and adaptability for wood volume in the selection of Eucalyptus saligna in three environments. Pesquisa Agropecuária Brasileira, Brasília, v. 53, n. 5, p. 611-619, 2018.

OSORIO, L. F.; WHITE, T. L.; HUBER,D. A. Age-age an dtrait-trait correlations for Eucalyptus grandis Hill ex Maiden and their implications for optimal selection age and design of clonal trials. Theorical and Applied Genetics, Frankfurt, v. 106, n. 4, p. 735-743, 2003.

PUPIN, S.; SANTOS, A. V. A., ZARUMA, D. U. G., MIRANDA, A. C., SILVA, P. H. M., MARINO, C. L.; SEBBENN, A. M.; MORAES, M. L. T. Produtividade, estabilidade e adaptabilidade em progênies de polinização aberta de Eucalyptus urophylla S.T. Blake. Scientia Forestalis, Piracicaba, v. 43, n. 105, p. 127-134, 2015.

PUPIN, S.; SILVA, P. H. M.; PIOTTO, F. A.; MIRANDA, A. C.; ZARUMA, D. U. G.; SEBBENN, A. M.; MORAES, M. L. T. Genotype x Environment interaction, stability, and adaptability in progenies of Eucalyptus urophylla ST Blake using the AMMI model. Silvae Genetica, Frankfurt, v. 67, n. 1, p. 51-56, 2018.

RESENDE, M. D. V.Selegen-Reml/Blup: sistema estatístico e seleção genética computadorizada via modelos lineares mistos.Colombo: Embrapa Florestas, 2007. 359 p.

ROSADO, A. M.; ROSADO, T. B.; ALVES, A. A.; LAVIOLA, B. G.; BHERING, L. L.Seleção simultânea de clones de eucalipto de acordo com produtividade, estabilidade e adaptabilidade. Pesquisa Agropecuária Brasileira, Brasília, v. 47, n. 7, p. 966-973, 2012.

SANTOS, G. A.; RESENDE, M. D. V.; SILVA, L. D; HIGA, A.; ASSIS, T. F.Interação genótipos x ambientes para produtividade de clones de Eucalyptus L'hér. no estado do Rio Grande do Sul. Revista Árvore, Viçosa, v. 39, n. 1, 2015.

SANTOS, G. A.; NUNES, A. C. P.; RESENDE, M. D. V.; SILVA, L. D.; HIGA, A.; ASSIS, T. F. An index combining volume and Pilodyn penetration to study stability and adaptability of Eucalyptus multi-species hybrids in Rio Grande do Sul, Brazil. Australian Forestry, v.79, p.248-255, 2016.

STAPE, J. L.; BINKLEY, D.; RYAN, M. G. Eucalyptus production and the supply, use and efficiency of use of water, light and nitrogen across a geographic gradient in Brazil. Forest Ecology and Management, Amsterdan, v. 193, n. 1-2, p. 17-31, 2004.

TAMBARUSSI, E. V.; LIMA, B. M.; QUEIROZ, R. C.; PERES, F. S. B. DIAS, D. C.; PAGLIARINI, M. K., PEREIRA, F. B.; ROSA, J. R. B. F.; REZENDE, G. D. S. P. Estimativas de parâmetros genéticos para a seleção precoce em clones de Eucalyptus spp. ScientiaForestalis, Piracicaba, v. 45, n. 115, 2017.

FLORESTA, Curitiba, PR, v. 50, n. 2, p. 1267 - 1278, abr/jun 2020.

Furlan, R. A. et.al.

ISSN eletrônico 1982-4688

DOI: $10.5380 /$ rf.v50 i2. 62524 
TEODORO, P. E.; BHERING, L. L.; COSTA, R. D.; ROCHA, R. B.; LAVIOLA, B. G. Mixed models for selection of Jatropha progenies with high adaptability and yields tability in Brazilian regions. Genetics and Molecular Research, v.15, 2016.

VENCOVSKY, R. Tamanho efetivo populacional na coleta e preservação de germoplasmas de espécies alógamas. IPEF, Piracicaba, n. 35, p.79-84, 1987.

VENCOVSKY, R.; BARRIGA, G. P. Genética biométrica no fitomelhoramento. Ribeirão Preto: Sociedade Brasileira de Genética, 1992. 486p. 